\title{
IMPLEMENTASI PROGRAM MAKASSAR TIDAK RANTASA (MTR) DI KECAMATAN TAMALATE KOTA MAKASSAR
}

\author{
Oleh: \\ SANGKALA IBSIK \\ MUH KHAEDIR \\ Dosen Jurusan PPKn FIS Universitas Negeri Makassar
}

\begin{abstract}
ABSTRAK: Metode penelitian ini termasuk penelitian Deskriptif Kualitatif. Tujuannya adalah (1) Untuk mengetahui program makassar tidak rantasa di kecamatan tamalate. (2) Untuk mengetahui implementasi program makassar tidak rantasa di kecematan tamalate. (3 Untuk mengetahui apa yang menjadi kendala masyarakat kecematan tamalate dalam memaksimalkan program Makassarta Tidak Rantasa. Penelitian ini adalah deskriptif kualitatif dan sampel sebanyak 30 RT (informan) yang ditarik secara purposive sampling yaitu penarikan sampel yang dilakukan secara sengaja dengan kriteria tertentu. Pengumpulan data dilakukuan dengan teknik wawancara mendalam, observasi dan dokumentasi. Hasil penelitian ini menunjukkan bahwa. (1) Program makassar tidak rantasa (MTR) yang dicanangkan Wali Kota Makassar sudah terlaksana tetapi belum maksimal khususnya yang ada di kelurahan mannuruki. Program MTR meliputi, Lihat Sampah Ambil (LISA), Lorong Gardeng (LONGGAR), kerja bakti massal, sampah tukar beras, aku dan sekolahku tidak rantasa. (2) Implementasi program makassar ta tidak rantasa yang ada di kelurahan mannuruki yaitu: Kerja bakti massal, sampah tukar beras, aku dan sekolahku tidak rantasa. (3) Kendala dalam pengimplementasian program makassar tidak rantasa di kelurahan mannuruki dapat dilihat dari segi faktor kesadaran masyarakat yang masih kurang, kurangnya fasilitas pengangkut sampah (gerobak sampah), sempitnya pekarangan maupun lahan kosong, kurangnya tempat sampah sementara, dan drainase.
\end{abstract}

\section{Kata Kunci: Program Makassar Tidak Rantasa}

ABSTRACT: This research method including qualitative descriptive study. The aim is (1) To determine the program in the district of Makassar not rantasa Tamalate. (2) To determine the program implementation makassar not rantasa in Kecematan Tamalate. (3 To find out what the problem is society Kecematan Tamalate in maximizing program Makassarta Not Rantasa. This research is descriptive and qualitative sample of $30 \mathrm{RT}$ (informer) drawn by purposive sampling, that the sampling is done intentionally by certain criteria. The data collection dilakukuan with depth interview, observation and documentation. the results showed that, (1) Program makassar not rantasa (MTR) launched by the Mayor of Makassar has been implemented but not maximum, especially in villages mannuruki. Program MTR covers, See Garbage Grab ( LISA), Lorong Gardeng (LOOSE), community service bulk, garbage exchange rice, I and my school does not rantasa. (2) the program implementation makassar ta not rantasa in villages mannuruki namely: work devotion bulk, garbage exchange rice, I and my school not rantasa. (3) Constraints in the implementation of the program makassar not rantasa in villages mannuruki can be seen in terms of factors of public awareness is still lacking, a lack of facilities of garbage (garbage carts), the narrowness of the yard or vacant land, the lack of trash while, and drainage.

Keywords: Program Makassar Not Rantasa 


\section{PENDAHULUAN}

Dalam undang-undang republik Indonesia nomor 32 tahun 2009 tentang perlindungan dan pengelolaan lingkungan hidup bab 1 pasal 1 dijelaskan bahwa: lingkungan hidup merupakan kesatuan ruang dengan semua benda, daya, keadaan, dan makhluk hidup, termasuk manusia dan perilakunya, yang mempengaruhi alam itu sendiri, kelangsungan perikehidupan, dan kesejahteraan manusia serta makhluk hidup lain. Sebagai manusia sudah menjadi kewajiban untuk menjaga, merawat dan melestarikan lingkungan hidup sebab lingkungan merupakan tempat manusia hidup sehingga lingkungan juga sangat mempengaruhi kualitas manusia. Jadi perlu diterapkan dan dimulai adanya pendidikan lingkungan hidup dalam dunia pendidikan maupun dalam lingkungan masyarakat terutama mengenai kebersihan yang merupakan pangkal dalam mencapai tujuan lingkungan hidup.

Peraturan daerah kota makassar Nomor 4 tahun 2011 tentang pengelolaan sampah menimbang: a. bahwa dalam rangka mewujudkan lingkungan yang sehat dan bersih dari sampah, perlu dilakukan penanganan sampah secara komprehensif dan terpadu dengan melibatkan peran serta masyarakat dan dunia usaha secara proporsional, efektif dan efisien; b. bahwa masalah persampahan perlu dilakukan pengelolaan secara komprehensif dan terpadu agar memberikan manfaat secara ekonomi, sehat bagi masyarakat dan aman bagi lingkungan serta dapat mengubah perilaku masyarakat; c. bahwa berdasarkan pertimbangan sebagaimana dimaksud dalam huruf a, dan b,perlu ditetapkan peratuaran daerah Kota Makassar tentang pengelolaan sampah.

Adanya pergantian kepimimpinan setiap lima tahun telah memberikan suasana segar yang merangsang lahirnya aneka gagasan pembangunan yang lebih kreatif dan sesuai dengan tuntutan masyarakat yang terus berkembang. Kepercayaan dan amanah ini merupakan tantangan yang tidak ringan. Apalagi dengan kompleksitas problematika kota yang kian variatif baik skala maupun dimensinya. Sekedar catatan Makassar kini memilikin luas wilayah kurang lebih $175,77 \mathrm{~km} 2$, berpenduduk sekitar 1,4 juta jiwa dan secara administratif pemerintahan terbagi dalam 14 kecematan dan 142 kelurahan. Artinya, pemerintah kota dituntut untuk pandai-pandi menempatkan diri secara pas sehingga dapat leluasa mewarnai dan menafasi denyut nadi pembangunan kota.

Makassar merupakan salah satu kota besar baik dari segi perekenomian serta volume penduduknya semakin meningkat baik dari penduduk asli Kota Makassar sampai pada orang-orang yang merantau seperti mencari kerja maupun menempuh pendidikan di kota yang dikenal dengan kota daeng. Perkembangan ini membuat banyak kalanganan yang menilai bahwa Makassar telah menjadi kota metropolitan serta menjadi salah satu kota pusat perdagangan di wilayah Indonesia Timur.

Masalah kebersihan tidak kunjung selesai hampir di setiap kota di Indonesia. Permasalahan ini muncul setiap tahun dan terus berlangsung tanpa ada solusi yang tepat dalam pelaksanaannya. Kondisi perkotaan yang masih jauh dari predikat kota bersih adalah hal yang masih menjadi info populer diangkat oleh banyak media setiap harinya. Ketika sampah masih banyak berserakan dimana-mana kerap dianggap tidak sesuai dengan visi kota yang sebagian besar menekankan aspek kebersihan, keindahan dan kerapihan kota atau kita kenal dengan istilah 3K. Oleh karena itu kebersihan, keindahan dan kerapihan seringkali menjadi target utama kebijakan-kebijakan pemerintah Kota Makassar.

Hal ini merupakan masalah yang sangat kompleks karena akan menghadapi banyak karakter atau perilaku masyarakat 
yang beragam. Perilaku masyarakat perkotaan yang relatif berbeda dalam menyikapi masalah kebersihan erat relevansinya dengan pendidikan atau pengetahuan tentang kesehatan yang tidak merata. Hal ini juga bisa dipengaruhi oleh kebiasaan masyarakat yang sudah berjalan dalam waktu yang lama tanpa adanya aturan atau sanksi yang bisa membuat jera. Masyarakat yang mempunyai kebiasaan buang sampah bukan pada tempatnya membuat kondisi kota menjadi memprihatinkan baik dari segi kebersihan, keindahan dan kerapihan begitupun dengan kesehatan masyarakat pada umumnya.

\section{TINJAUAN PUSTAKA}

\section{Program Makassar Tidak Rantasa (MTR)}

a) Maksud Makassar Tidak Rantasa

Gerakan Makassarta Tidak Rantasa' (Gemar MTR) dicanangkan Wali Kota Makassar, Mohammad Ramadhan Pomanto April 2014. Program ini merupakan wujud nyata, komitmen, dan tingginya kepedulian pemerintah kota Makassar dalam menjadikan Makassar sebagi kota dunia yang nyaman dan tidak rantasa, ${ }^{33}$.

Dalam bahasa daerah Makassar, tidak rantasa' memiliki arti tidak jorok. Seperti penamaannya, program ini diharapkan bias menjadi inspirasi dan pelecut semangat segenap warga kota dalam mewujudkan Makassar dua kali lebih baik.

Gemar MTR tidak hanya sekadar program. Kegiatan ini justru merupakan wujud penyadaran warga dalam mengubah pola piker dan berperang melawan kejorokan. Gerakan ini juga dianggap sebagai bagian dari budaya siri' na pace yang menjadi pegangan hidup masyarakat Bugis dan Makassar.

b) Hakekat Pentingnya Perilaku Masyarakat Lingkungan Bersih Pengertian perilaku didalam Kamus Besar Bahasa Indonesia,yang berasal dari kata Laku adalah : "Perbuatan; Kelakuan; Cara menjalankan atau berbuat. ${ }^{34}$

Suatu perbuatan seseorang yang berhubungan dengan keseharianhariannya dalam kehidupan bermasyarakat sangat berkaitan dengan kemampuan seseorang dalam menilai perilaku seseorang dapat dikatakan baik dan buruk. Perilaku adalah suatu perbuatan yang menjadi suatu kebiasaan sehari-hari seseorang serta berkaitan dengan sikap yang dimiliki orang tersebut.

Pengertian tingkah laku Menurut Azis Wahab yaitu: "Tingkah laku berupa perangai, akhlak dan watak, merupakan alat batin dan panduan akal dan perasaan untuk menimbang baik dan buruk." 35

\section{Pengimplementasian Program Makassar Tidak Rantasa'}

a) Sampah Tukar Beras

Program pemerintah Kota Makassar sampah ditukar beras pun tak pelak mendapatkan apresiasi yang baik dari warga. Hal ini terlihat dari animo masyarakat yang menukar sampah mereka dengan beras. Untuk mendapatkan lima liter beras warga mesti mengumpulkan tiga karung beras sampah. Dimana tiap karung beratnya tujuh kilogram untuk penukaran sampah dengan beras efektif dilakukan tiap akhir pekan. Dengan adanya program ini selain dapat membantu ekonomi warga juga menciptakan kebersihan di lingkungan sekitar yang tentu saja berdampak bagi

\footnotetext{
${ }^{33}$ Rusdin Tompo,Masa Depan Makassar Dinamika Demokrasi dan

Pemerintahan,Makassar, Badan Arsip Perpustakaan dan Pengolahan Data Kota Makassar, 2014, hlm. 147
}

34 Tim Penyusun,,Kamus Besar Bahasa Indonesia(Jakarta : Balai Pustaka,2000), hlm. 488

35 Azis Wahab, Implementasi dan arah Perkembangan PKn,(Bandung: Rosda Karya ,2001), hlm.21 
estetika kota dan juga menciptakan lingkungan yang sehat dan bersih. ${ }^{36}$

\section{b) Kerja Bakti Massal}

Pemerintah Kota Makassar makin mengitensifkan kerja bakti di tempattempat umum di Kota Makassar. Jika sebelumnya hanya dilakukan sekali dalam sepekan, kini dilakukan dua kali sepekan diakhir pekan.

Kerja bakti lompoa dilaksanakan setiap hari jum'at pagi, digelar secara besar-besaran di seluruh kelurahan. Selain masyarakat, ratusan pegawai dan warga turun ke jalan membersihkan saluran air dan ruas jalan dari sampah yang bertebaran. Tujuannya, agar masyarakat untuk ikut berperan serta dalam kerja bakti lompoa ini. ${ }^{37}$

c) Aku dan Sekolahku Tidak Rantasa'

Wali kota Makassar, Moh Ramadhan "Danny" Pomanto meluncurkan program Aku dan Sekolahku Tidak Rantasa di SMP 30 Makassar, Jumat, 29/8/2014. Pemkot Makassar melibatkan seluruh siswa se-Kota Makassar untuk turun kejalan membersihkan Kota Makassar yang dikemas dalam bentuk program Aku dan Sekolahku Tidak Rantasa', ${ }^{38}$

\section{METODE PENELITIAN}

Berdasarkan variabel yang dikaji yakni "Implementasi Program Makassar Tidak Rantasa' (MTR) Di Kecamatan Tamalatea Kota Makassar" menggunakan variabel tunggal sehingga tidak mengaitkan atau mengkaji hubungan antara variabel lainnya. Dalam penelitian ini, digunakan desain deskriptif kualitatif yang bertujuan untuk menggambarkan proses atau bentuk pengimplementasian program Makassar Tidak Rantasa' (MTR) dengan mengumpulkan informasi yang terperinci melalui prosedur pengumpulan data.
Dalam penelitian ini, subjek penelitiannya adalah 30 RT yang ada di kelurahan mannuruki kecamatan tamalate. Mengingat jumlah populasi yang tidak terlalu besar maka penelitian ini adalah penelitian yang teknik penarikan sampelnya menggunakan teknik total sampling yakni penentuan sampel sesuai dengan jumlah populasi yang ada. Namun untuk melengkapi data dari penelitian ini, maka peneliti perlu mendapatkan informasi dari masyarakat tentang penerapan program Makassarta' Tidak Rantasa' oleh Pemkot Makassar yang dimana teknik pengumpulan datanya menggunakan random sampling. Sebab, peneliti akan meminta informasi yang sifatnya tidak terstruktur atau secara acak dari masyarakat sesuai kebutuhan dari data yang ingin diperoleh.

Penggunaan teknik pengumpulan data ini sifatnya lebih disesuaikan pada analisis kebutuhan dan kemampuan peneliti itu sendiri. Oleh karenanya, teknik pengumpulan data yang digunakan adalah wawancara mendalam (deep interview) yakni dilakukan tanya jawab secara langsung antara peneliti dengan pihak masyarakat Kecematan Tamalate dalam hal untuk meminta informasi tentang pengimplementasian program Makassar Tidak Rantasa' (MTR)

Data yang kemudian terhimpun selanjutnya dianalisis dengan menggunakan teknik analisis deskriptif kualitatif yaitu menjabarkan peristiwaperistiwa yang diteliti.

\section{HASIL PENELITIAN DAN PEMBAHASAN}

\section{Program Makassar Tidak Rantasa}

Program Makassar tidak rantasa merupakan program yang dicanangkan wali kota Makassar untuk bisa mengubah perilaku masyarakat yang tidak sadar akan pentingnya lingkungan yang bersih. $\begin{array}{ll}{ }^{36} \text { Badan arsip, perpustakaan dan pengolahan } & { }^{37} \mathrm{Ibid}: \mathrm{hlm} .42 \\ \text { data kota Makassar, Gerakan Makassarta Tidak } & { }^{38} \mathrm{Ibid}: \mathrm{hlm} .43\end{array}$

$\begin{array}{ll}{ }^{36} \text { Badan arsip, perpustakaan dan pengolahan } & { }^{37} \mathrm{Ibid}: \mathrm{hlm} .42 \\ \text { data kota Makassar, Gerakan Makassarta Tidak } & { }^{38} \mathrm{Ibid}: \mathrm{hlm} .43\end{array}$

Rantasa,(Makassar : 2014), hlm. 41 
Program Makassar tidak rantasa sangat luas cakupannya bukan hanya sampah yang terkandung di dalamnya tetapi banyak hal diantaranya mengenai pedagang kaki lima yang berjualan di terotoar jalan sehingga inilah yang menyebabkan kemacetan bagi pengguna jalan. Jadi inilah salah satu maksud dari wali kota Makassar yakni makassar tidak rantasa agar masyarakat dapat melaksanakan apa yang menjadi perubahan yang ada di Makassar khususnya masyarakat mannuruki agar programnya ini bisa terlaksana dengan baik tentunya perlu ada dukungan dari semua pihak, terkhusus kepada masyarakat karena meskipun program Makassar ta Tidak Rantasa ini sudah di sosialisasikan kalau masyarakat tidak bisa bekerja sama dalam artian bahwa ada timbal balik dengan pemerintah kota Makassar, terkhusus dikelurahan mannuruki kecamatan Tamalate. Kelurahan mannuruki mempunyai 8 RW (rukun warga) dan sebanyak 30 RT (rukun tetangga).

a. Lihat Sampah Ambil (LISA)

Program Makassar ta tidak rantasa adalah bagaimana masyarakat harus menyadari dan memahami apa yang terkandung dalam program yang di perintahkan oleh wali kota Makassar ini seperti LISA. Jadi mengenai LISA ini dapat diterapakan dalam kehidupan sehari-hari karena sangat bermanfaat bagi diri sendiri bahkan sangat bermanfaat bagi orang lain, karena secara tidak langsung dapat meminimalisir sampahsampah yang dibuang sembarang tempat. Selain itu LISA ini sangat membantu petugas kebersihan karena tidak kewalahan ketika menyapu setiap harinya, utamanya yang ada di pinggir jalan.

b. Lorong Gardeng (LONGGAR)

Lorong gardeng salah satu upaya yang dilakukan setiap warga yang ada di kelurahan mannuruki untuk memperindah lorong-lorong yang di tempatinya seperti yang yang dilakukan di RW 03 Kelurahan Mannuruki program Makassar ta tidak rantas sudah terlaksana, dengan dukungan dari warga yang membuat Lorong Gardeng (LONGGAR) dan penulisan Lihat Sampah Ambil (LISA) jadi dengan adanya dukungan dari warga dapat tercipta suasana yang nyaman bagi pengguna jalan yang memasuki lorong.

c. Kerja bakti massal

Kerja bakti massal yang dilakukan setiap RW wujud dari program makassar tidak rantasa.

d. Sampah tukar beras

Sampah tukar beras yang merupakan isi dari program makassar tidak rantasa dan adanya partisipasi dari masyarakat dapat mengurangi sampahsampah yang ada di lingkungan warga.

e. Aku dan sekolahku tidak rantasa

Aku dan sekolahku tidak rantasa adalah bentuk keterlibatan peserta didik dalam menangani kebersihan di setiap sekolah agar tercipta lingkungan yang bersih.

\section{Implementasi Makassar Tidak Rantasa}

Implementasi program makassar tidak rantasa salah satu upaya yang dilakukan masyarakat untuk menangani masalah kebersihan yang tidak kunjung selesai karena hampir setiap kecamatan yang ada dimakassar mengalami permasalahan yang berkaitan dengan pengelolaan kebersihan. Terkhusus di kecamatan tamalate kelurahan mannuruki upaya yang dilakukan warga adalah menghiasi atau menata setiap lorong dengan menanam bunga disetiap pot, ada pot yang digantung sehinggan ini yang akan mempercantik pemandangan ketika memasuki lorong yang ada di kelurahan mannuruki yang keseluruhan terdapat 8 RW (rukun warga) dan sebanyak 30 (rukun tetangga). Jadi implementasi program Makassartidak rantasa perlu ada dukungan penuh dan parstisipasi dari masyarakat untuk memaksimalkan program Makassar ta tidak rantasa karena kesadaran masyarakat sangat perlu 
dibutuhkan agar masalah kebersihan bisa diatasi dengan baik.

a. Kerja Bakti Massal

Salah satu implementasi Makassar ta tidak rantasa adalah kerja bakti, dimana masyarakat ikut serta dalam menyukseskan program wali kota Makassar, kerja bakti yang dilakukan dapat menambah semangat dalam menangani sampah-sampah yang bersarakan, karena dilakukan dengan banyak orang pasti ada rasa bangga tersendiri ketika melihat lingkungan rumah sudah indah, bersih ketika di pandang hal ini terlihat di RT 02, RW 08 kelurahan mannuruki.

b. Sampah Tukar Beras

Sampah tukar beras merupakan isi dari implementasi makassar tidak rantasa yang dilakukan setiap warga untuk menangani masalah sampah yang selalu menjadi permasalahan warga.

c. Aku dan sekolahku tidak rantasa Dalam pengimplemetasian program makassar tidak rantasa yakni aku dan sekolahku tidak rantasa sangat perlu diperhatikan khususnya semua guru sekolah harus memberi contoh yang baik untuk siswanya utamanya dalam hal kebersihan, karena ketika kebersiahn dapat dilaksankan dengan baik maka pembelajaran dapat terlaksana dengan baik karena tercipta kondisi yang nyaman.

\section{Kendala Implementasi Program Makassar Tidak Rantasa}

Kendala program Makassar tidak rantasa merupakan faktor serius yang harus ditangani oleh masyarakat kelurahan mannuruki kecematan tamalate. Jadi berbicara tengtang kendala atau hamabatan dalam pengimplementasian Makassar ta tidak rantasa' mempunyai faktor diantaranya yaitu:

a. Faktor kesadaran

Faktor kesadaran yaitu dimana masyarakat kurangnya pemahaman tentang adanya lingkungan yang bersih dan tidak memikirkan dampak-dampak yang dihasilkan ketika membuang sampah disembarang tempat sehingga ini akan mempermudah berkembang biaknya nyamuk sehingga akan menimbulkan berbagai penyakit diantaranya penyakit malaria, bahkan selain menimbulkan penyakit juga akan berdampak banjir ketika musim hujan tibah karena sampah akan bertumpuk di sembarang tempat bahkan di got. Jadi perlu adanya kesadaran dari masyarakat tentang adanya lingkungan yang bersih sehinggah akan tercipta kondisi yang nyaman untuk hidup dalam kehidupan bermasyarakat. Dalam hidup bermasyarakat tentu adanya saling kerja sama antar sesama masyarakat terkhusus pada pemerintah yang mencanangkan program Makassar ta tidak rantasa. Jadi perlu dipahami bahwa dalam sebuah gerakan yakni Makassar ta tidak rantasa, untuk menjadi masyarakat yang baik, paham atau mengerti tentang adanya kebersihan tidak semudah yang kita bayangkan pasti terdapat berbagai masalah yang dihadapi.

b. Kurangnya fasilitas pengangkutan sampah atau gerobak sampah

Kurangnya pengangkut sampah yang mengambil sampah warga disetiap RT yang setiap harinya, salah satu penghambat yang dialami warga.

c. Sempitnya pekarangan sendiri maupun lahan kosong

Rumah yang ada di kelurahan mannuruki,sangat padat dan jarak antara dengan satu rumah dengan rumah yang lain saling berdekatan sehingga tidak dapat mengurangi mengubur, menampung atau membakar sampah,dan ketiadaan lahan untuk menaruh tempat sampah sementara.

d. Kurangnya tempat sampah sementara (TPS)

Kurangnya tempat sampah sementara seperti bak sampah untuk masing-masing rumah tangga maupun tempat sampah umum. Lalu kurang meratanya pemberian gerobak untuk masing-masing lingkungan seperti yang dialami RT 02. RW 04 kelurahan mannuruki. Kurang meratanya pengangkutan sampah oleh truk sampah 
atau gerobak sampah padahal warga mengaku siap mengeluarkan iuran. Bak sampah yang tersedia di beberapa lingkungan warga sehingga ketika orang membuang sampah itu seenaknya saja. Perbedaan peran serta dan kendala yang dihadapi masing-masing warga dilatarbelakangi oleh berbagai faktor, seperti lingkungan warga yang sempit,dan fasilitas pembuang sampah. Karena perbedaan kendala, maka masing-masing warga dapat melakukan pengelolaan sampah yang berbeda pula.

e. Drainase

Dalam pengimplementasian makassar tidak rantasa salah faktor kendalanya yaitu drainase yang sering banjir ketika musim hujan tiba.

\section{PENUTUP}

\section{Kesimpulan}

Berdasarkan hasil penelitian yang telah dibahas, maka dapat di kemukakan kesimpulan sebagai berikut:

1. Program makassar tidak rantasa (MTR) yang dicanangkan Wali Kota Makassar merupakan salah satu upaya untuk menangani kebersihan yang ada di Kota Makassar khususnya yang ada di kelurahan mannuruki. Program MTR meliputi, Lihat Sampah Ambil (LISA), Lorong Gardeng (LONGGAR), kerja bakti massal, sampah tukar beras, aku dan sekolahku tidak rantasa.

2. Implementasi program makassar ta tidak rantasa yang ada di kelurahan mannuruki yaitu: Kerja bakti massal, sampah tukar beras, aku dan sekolahku tidak rantasa.

3. Kendala dalam pengimplementasian program makassar ta tidak rantasa di kelurahan mannuruki dapat dilihat dari segi faktor kesadaran masyarakat yang masih kurang, kurangnya fasilitas pengangkut sampah (gerobak sampah), sempitnya pekarangan maupun lahan kosong, kurangnya tempat sampah sementara, dan drainase.

\section{Saran}

1. Kepada ketua RW Rukun Warga (RW) kelurahan mannuruki agar kiranya dapat melaksanakan program Makassar tidak rantasa yang merupakan amanat dari wali kota makassar demi mewujudkan cita-cita makassar sebagai kota dunia,dan selalu mengontrol tiap Rukun Tetangga (RT) agar tetap terjadi koordiasi yang baik sehingga program Makassar tidak rantasa dapat diwujudkan dengan baik.

2. Kepada ketua RT kelurahan mannuruki agar selalu mengkoordinir setiap RT untuk melakasanakan isi dari program makassar tidak rantasa.

3. Kepada warga khususnya yang di kelurahan mannuruki agar selalu menata lorongnya dengan baik dan pot dirapikan, supaya tercipta pemandangan yang indah ketika orang melewatinya, kebersihan halaman rumah/pekarangan rumah agar selalu dibersihkan tiap pagi, kebersihan got selalu di jaga dengan baik sehingga ketika musim hujan tiba air bisa mengalir dengan baik, dan selalu melakukan kerja bakti yang merupakan isi dari program makassar tidak rantasa.

4. Kepada sekolah yang ada di kelurahan mannuruki agar selalu menjaga kebersihan di lingkungan sekolahnya agar tercipta suasana yang nyaman ketika proses belajar mengajar berlangsung.

5. Kepada semua warga terkhusus di wilayah kelurahan mannuruki agar selalu menjaga kebersihan dan tetap patuh kepada pemerintah atas segala instruksinya ataupun kebijakan yang dikeluarkan sebab demi kepentingan bersama agar tercipta lingkungan yang bersih.

6. Kepada pemerintah kota Makassar agar selalu memfasilitasi kebutuhan masyarakat untuk melaksanakan program Makassar tidak rantasa. 
DAFTAR PUSTAKA

Tim Penyusun. 2000. Kamus Besar Bahasa Indonesia. Balai Pustaka: Jakarta

Azis Wahab. 2001. Implementasi dan arah Perkembangan PKn. Rosda Karya: Bandung

Noeng Muhadjir. 2000. Pengukuran Kepribadian. Reka Press: Jogyakarta

Saifudin Anwar. 2001. Sikap Manusia. Pustaka Pelajar: Jogyakarta

Bohar Suharto. 2000. Bimbingan Karya Ilmiah Sosial. Tarsito: Bandung

Sekretariat Negara. 2001. Gerakan Disiplin Nasional. Novindo Mandiri: Jakarta

Y.Matsui. 2001. Lingkungan Hidup. JICA: Jakarta

Anna Alisyahbana. 2004. Мепији Kesejahtraan Jiwa. Gramedia: Jakarta

Soerjono Soekamto. 2003. Pribadi dan Masyarakat. Alumni: Bandung

Endang Jaelani Sukaya dkk. 2002. PKn Untuk Perguruan Tinggi. Paradigma: Jogyakarta

Miriam Budiarjo. 2000. Dasar-dasar Ilmu Politik. Gramedia Pustaka Utama: Jakarta

Rafael Raga Maran. 2001. Sosiologi Politik. Rineke Putra: Jakarta

Kuncoro Ningrat. 2004. Pengantar Ilmu Antropologi. Rineke Cipta: Jakarta

Tim Penyusun. 2003. Pengantar Ilmu Pengetahuan Sosial. Aksara Baru: Jogyakarta

Agus Awijanto. 2003. Psikologi Umum. Aksara Baru: Jogyakarta

Alex. 2012. Sukses Mengolah Sampah Organik Menjadi Pupuk Organik. Pustaka Baru Press: Yogyakarta

Rusdin Tompo. 2014. Masa Depan Makassar Dinamika Demokrasi dan Pemerintahan Makassar. Badan Arsip Perpustakaan dan
Pengolahan Data Kota Makassar: Makassar

Badan arsip. 2014. Gerakan Makassarta

Tidak Rantasa. Perpustakaan dan Pengolahan Data Kota Makassar: Makassar. 